\title{
Pendekataan Keterampilan Proses Dalam Meningkatkan Hasil Belajar Siswa Pada Materi Cerita Anak Kelas V
}

\author{
Hadi Rohyana \\ Institut Daarul Qur'an, Jakarta, Indonesia \\ *Corresponding author: hadi.rohyana@gmail.com
}

\begin{abstract}
This research is a classroom action research with a focus on the problem of applying the process skills approach in improving student learning outcomes. The purpose of the study was to determine the improvement of student learning outcomes by using a process skills approach to the story material for Indonesian children in the fifth grade of elementary school. The process skills approach emphasizes the student's learning process to determine understanding and cohesiveness about the material being taught then students will immediately observe and then be able to follow themselves, the number of students is 23 students consisting of 13 male students, 10 female students in class V SD Negeri 2 Danawinangun, Klangenan District, Cirebon Regency. This research method uses Classroom Action Research (CAR) which is carried out in 2 cycles using the Kemmis and Taggart spiral models. Test and non-test data collection techniques. Data collection instruments are essay tests, observations, documentation. Based on the results of the study showed that in the first cycle after using the process skills approach there was an increase in student learning outcomes that were completed, namely $65.2 \%$ or an increase of $43.5 \%$ from the previous. This condition increased significantly in Cycle II, students who achieved mastery in learning Indonesian increased by $86.9 \%$ or up from cycle I. The conclusion of the research shows that the application of the process skills approach is effective in improving student learning outcomes in children's story material Indonesian.
\end{abstract}

Keywords: children's stories; learning outcomes; process skills

\section{ABSTRAK}

Penelitian ini merupakan penelitian tindakan kelas dengan fokus masalah tentang penerapan pendekatan keterampilan proses dalam meningkatkan hasil belajar siswa. Tujuan penelitian adalah untuk mengetahui peningkatan hasil belajar siswa dengan menggunakan pendekatan keterampilan proses pada materi cerita anak pelajaran Bahasa Indonesia di kelas V SD. Pendekatan keterampilan proses menekankan kepada proses belajar siswa untuk menentukan pemahaman dan kesatupaduan tentang materi yang diajarkan kemudian siswa akan langsung mengamati dan kemudian bisa mnegikuti sendiri, jumlah siswa 23 siswa yang terdiri 13 siswa laki-laki, 10 siswa perempuan kelas $\mathrm{V}$ SD Negeri 2 Danawinangun, Kecamatan Klangenan, Kabupaten Cirebon. Metode Penelitian ini menggunakan Penelitian Tindakan Kelas (PTK) yang dilakukan dalam 2 siklus menggunakan model spiral Kemmis dan Taggart. Teknik pengumpulan data tes dan non tes. Instrumen pengumpulan data yaitu tes essai, observasi, dokumentasi. Berdasarkan Hasil penelitian menunjukkan pada siklus I setelah menggunakan pendekatan keterampilan proses ada peningkatan hasil belajar siswa yang tuntas yaitu $65,2 \%$ atau naik $43,5 \%$ dari sebelumnya. Kondisi yang demikian ini semakin meningkat signifikan pada Siklus II siswa yang mencapai ketuntasan dalam pembelajaran Bahasa Indonesia meningkat sebanyak $86,9 \%$ atau naik dari siklus I. Kesimpulan hasil penelitian menunjukan bahwa penerapan pendekatan keterampilan proses efektif dalam meningkatkan hasil belajar siswa pada materi cerita anak pelajaran bahasa Indonesia.

Kata Kunci: cerita anak; hasil belajar; keterampilan proses

\section{Pendahuluan}

Hasil belajar siswa merupakan salah satu tujuan dari proses pembelajaran disekolah, maka dari itu seorang guru perlu mempelajari beberapa metode dan pendekatan pembelajaran yang dipraktekan pada saat mengajar. Untuk menghasilkan prestasi (hasil) belajar siswa yang tinggi, guru dituntut untuk mendidik dan mengajar siswa dengan menggunakan metode pembelajaran yang dibutuhkan dalam proses pembelajaran di kelas. Djamarah dan Zain (2010) 
menyebutkan bahwa kedudukan metode adalah sebagai alat motivasi ekstrinsik, sebagai strategi pengajaran dan juga sebagai alat untuk mencapai tujuan

Roestiyah (2001) mengatakan guru harus memiliki strategi agar anak didik dapat belajar secara efektif dan efesien, pada tujuan yang diharapkan. Sebagai seorang tenaga Pendidikan guru harus bisa menguasai keadaan kelas sehingga tercipta suasana belajar yang menyenangkan, untuk menghasilkan proses pembelajaran yang berkualitas, seorang guru membutuhkan metode pembelajaran yang baik pula, yang mampu memberikan dampak positif terhadap hasil belajar siswa, sehingga dibutuhkan kemampuan guru dalam menerapkan metode pembelajaran yang sesuai degan karakteristik peserta didiknya.

Setiap proses pembelajaran guru menghendaki agar siswa didiknya memperoleh prestasi belajar yang optimal atau setidaknya memenuhi Setandar Ketuntasan Belajar Minimal (SKBM) yang telah ditetapkan.Guru yang profesional adalah guru yang memiliki kemampuan mengajar yang mantap, mampu membuat perencanaan, mampu melaksanakan pembelajaran dan mampu mengevaluasinya. Sebagai penentu keberhasilan maka posisi guru sangat strategis. Berdasarkan hasil observasi awal menunjukkan bahwa permasalahan dalam pembelajaran tentang materi cerita anak dalam mengidentifikasi watak, tokoh, latar, tema atau amanat dari suatu cerita pada siswa kelas V SDN 2 Danawinangun masih rendah, yaitu hanya 21,7\% saja. Hal tersebut terjadi karena (1) jumlah siswa yang terlalu banyak sehingga perhatian guru tidak merata, (2) pemahaman siswa yang masih rendah karena guru tidak memberikan koreksi dan balikan yang sesuai bagi siswa, (3) pembagian tugas pada siswa yang tidak merata sehingga kegiatan pembelajaran hanya didominasi oleh beberapa siswa, dan (4) pembelajaran tidak menarik bagi siswa karena demonstrasi yang dilakukan oleh guru sudah dapat ditebak oleh siswa hasilnya.

Dapat dikatakan bahwa adanya hasil belajar siswa yang tinggi dan berkualitas, dapat dihasilkan dari proses pembelajaran yang berkualitas, untuk menghasilkan proses pembelajaran yang berkualitas seorang guru harus memiliki kemampuan dalam menerapkan pendekatan pembelajaran yang sesuai dengan kebutuhan dalam kelas, ketidaksesuaian pendekatan pembelajaran yang diterapkan dapat menurunkan kualitas proses pembelajaran itu sendiri, dengan demikian maka perbaikan dan peningkatan hasil belajar siswa di sekolah dapat dilaksanakan dengan adanya penggunaan pendekatan pembelajaran yang tepat oleh guru.

Salah satu upaya untuk meningkatkan keberhasilan belajar siswa, yaitu dengan menggunakan pembelajaran aktif di mana siswa melakukan sebagian besar pekerjaan yang harus dilakukan. Siswa menggunakan otak untuk melakukan pekerjaannya, mengeluarkan gagasan, memecahkan masalah dan dapat menerapkan apa yang mereka pelajari. Dengan demikian akan diketahui sejauh mana tingkat keberhasilan siswa dalam menyerap materi yang diajarkan serta lebih penting lagi siswa dapat mengimplementasiakan di dalam kehidupan sehari-hari.

Bahasa adalah sarana komunikasi yang penting bagi manusia. Melalui bahasa, seseorang dapat menyampaikan ide atau gagasan kepada orang lain. Tarigan (2009) menyatakan keterampilan berbahasa sangat penting dimiliki oleh setiap manusia karena bahasa seseorang mencerminkan pikirannya. Semakin terampil seseorang dalam berbahasa, maka semakin jelas pula jalan pikiran orang tersebut. Selain itu, Budinuryanta, dkk (1997) 
menyatakan bahwa pembelajaran keterampilan berbahasa di sekolah juga bertujuan untuk meningkatkan kemampuan intelektual, kematangan emosional, dan sosial. Berdasarkan pernyataan tersebut dapat disimpulkan bahwa pengajaran berbahasa berkaitan pula dengan kegiatan mendidik siswa dari berbagai aspek.

Keterampilan berbahasa meliputi empat keterampilan dasar, yaitu: menyimak, berbicara, membaca, dan menulis. Setiap keterampilan mempunyai hubungan erat dengan keterampilan lainnya. Keterampilan-keterampilan tersebut hanya dapat diperoleh dan dikuasai dengan jalan praktik dan latihan yang banyak. keterampilan berbahasa biasanya diperoleh manusia secara berurutan. Keterampilan berbahasa yang pertama kali dikuasai manusia adalah menyimak dan berbicara baru kemudian membaca dan menulis. Keterampilan menyimak dan berbicara dipelajari sebelum memasuki jenjang sekolah, sedangkan membaca dan menulis dipelajari saat memasuki jenjang sekolah.

Fungsi bahasa sendiri secara umum memiliki fungsi personal dan sosial. Fungsi sosial mengacu pada peranan bahasa sebagai alat untuk mengungkapkan pikiran dan perasaan setiap diri manusia sebagai makluk individu. Bahasa juga memiliki peran penting dalam perkembangan intelektual, sosial, dan emosional. Bahasa Indonesia merupakan bahasa pengantar pendidikan disemua jenis jenjang pendidikan mulai dari pendidikan dasar khususnya sekolah dasar, menengah hingga pendidikan tinggi. Oleh karenanya, bahasa merupakan kunci pokok bagi kehidupan manusia di atas dunia ini. Karena dengan bahasa, orang dapat berinteraksi dengan sesamanya dan bahasa merupakan sumber daya bagi kehidupan bermasyarakat. Dengan bahasa juga seseorang dapat mengungkapkan perasaan.

Dikaitkan dengan konteks pendidikan dasar sembilan tahun maka fungsi dan tujuan pendidikan bahasa Indonesia disekolah dasar harus pula mendukung pemilikan kompetensi tamatan sekolah dasar, yaitu pengetahuan, nilai, sikap, dan kemampuan melaksanakan tugas ataun mempunya kemampuan mendekatkan dirinya dengan lingkungan alam, lingkungan sosial, lingkungan budaya, dan kebutuhan daerah. Sementara itu, kondisi pendidikan bahasa Indonesia di Negara kita ini, lebih diwarnai oleh pendekatan yang menitiberatkan pada model pembelajaran konvensional seperti ceramah sehingga kurang mampu merangsang siswa untuk terlibat aktif.

Beberapa pemaparan yang telah disampaikan dapat disimpulkan bahwa keterampilan berbahasa mencakup empat keterampilan dan sesuai dengan pernyataan dari Tarigan (Djuanda. 2008) yaitu, keterampilan menyimak (Listening skill), keterampilan berbicara (Speaking skill), keterampilan membaca (Reading Skill) dan keterampilan menulis (Writing skill). Keempat keterampilan berbahasa pada dasarnya dalam tujuan pembelajaran bahasa harus tercapai, khususnya pembelajaran bahasa Indonesia. Selain diarahkan untuk meningkatkan kemampuan siswa dalam berkomunikasi baik secara lisan maupun tulisan, bahasa juga bermanfaat sebagai sarana apresiasi sastra dan prosa.

Menurut Syaiful (2013) mengemukakan, pendekatan pemberian kesempatan kepada siswa untuk ikut menghayati proses penemuan dan penyususnan suatu konsep sebagai suatu keterampilan. Pembelajaran menekankan pada proses dilatarbelakangi oleh konsep-konsep. Belajar menurut teori "Naturalisme-Romantis" menekankan kepada aktifitas siswa, dan teori "kognitif Gestalf" menekankan kepahaman dan kesatupaduan yang menyeluruh pendekatan proses dalam pembelajaran dikenal pula sebagai keterampilan proses, guru menciptakan bentuk kegiatan pengajaran yang bervariasi, agar siswa terlibat dalam berbagai pengalaman. 
Siswa melakukan kegiatan sebagai berikut: a) Percobaan, b) Pengamatan, c) Pengukuran, d) Perhitungan, d) Dan membuat kesimpulan sendiri

Pendekatan proses ini siswa tidak hanya belajar dari guru, tetapi juga dari sesama temannya, dari manusia-manusia sumber diluar sekolah kegiatan-kegiatan yang dilakukan oleh siswa dalam pembelajaran yang menggunakan pendekatan proses adalah: a) Mengamati gejala yang timbul, b) Mengklasifikasi sifat yang sama, serupa, c) Mengkur besaran-besaran yang bersangkutan, d) Mencari hubungan antara konsep yang ada, e) Mengenal adanya suatu masalah, merumuskan masalah, f) Memperkirakan penyebab suatu gejala, merumuskan hipotesis, g) Meramalkan gejala yang mungkin akan terjadi, h) Berlatih menggunakan alat-alat ukur, i) Melakukan percobaan, j) Mengumpulkan, menganalisis, dan menafsirkan, k) Berkomunikasi, 1) Mengenal adanya fariabel, pengendalian suatu fariabel. Pendekatan keterampilan proses merupakan pendekatan pembelajaran yang menekankan pada proses belajar, aktivitas dan kreativitas peseta didik dalam memperoleh pengetahuan, keterampilan, nilai dan sikap serta menerapkanya kedalam kehidupan sehari-hari.

Menurut Azhar (2016) keterampilan proses merupakan kemampua siswa untuk mengelola ( memperoleh ) yang didapat dalam kegiatan belajar mengajar ( KBM ) yang memberikan kesempatan pada siswa untuk mengamati, menggolongkan, menafsirkan, meramalkan, menerapkan, merencanakan penelitian. Sementara menurut Conny dkk Pendekatan keterampilan proses adalah pengembangan sistem belajar yang mengefektifkan siswa (CBSA) dengan cara pengembangan proses perolehan pengetahuan sehingga peserta didik akan menemukan, mengembangkan sendiri fakta dan konsep, serta menumbuhkan sikap dan nilai dalam tujuan pembelajaran.

Menurut Dimyati (2002) Mengatakn bahwa: a) Pendekatan keterampilan proses memberikan pengertian yang tepat tentang hakekat ilmu pengetahuan. Siswa mngalamai rangsangan ilmu pengetahuan dan dapat lebih baik mengerti fakta dan konsep ilmu pengetahuan. b) Mengajar dengan keterampilan proses berarti memberikan kesempatan kepada siswa bekerja dengan ilmu pengetahuan, tidak hanya menceritakan atau mendengarkan cerita tentang ilmu pengetahuan. c) Menggunakan keertampilan proses untuk mengajar ilmu pengetahuan membuat siswa belajar proses dan produk ilmu pengetahuan sekaligus. Menurut Syaiful (2013). Pendekatan proses adalah suatu pendekatan pengajaran pemberian kesempatan kepada siswa untuk menghayati proses penemuan atau penyusunan suatu konsep sebagai suatu keterampilan proses. Pembelajaran dengan menekankan kepada proses dilatar belkangi oleh konsep - konsep belajar.

Pendekatan proses dalam pembelajaran dikenal pula sebagai keterampilan proses dalam pembelajaran berfariasi agar siswa terlibat dalam berbagai pengamatan, dan menilai sendiri suatu kegiatan. Siswa melakukan percobaan, pengamatan, pengukuran, perhitungan dan membuat kesimpulan - kesimpulan sendiri. Pendekatan Keterampilan Proses pada hakikatnya merupakan suatu pengelolahan kegiyatab belajar-mengajar pada pelibatan siswa secara aktif dan kratif dalam proses pemerolehan hasil belajar (Santosa, 2008).

Pendekatan Keterampilan Proses memfokuskan kegiyatan belajar mengajar dapa proses pemerolehan hasil belajar dan mencapai tujuan pembelajaran itu sendiri. Pendekatan ini menumbuhkan kemampuan-kemampuan dasar untuk memperoleh pengetahuan, pengalaman, dan kemampuan yang meliputi kemampuan seperti yang dijelaskan oleh Syae'I dalam Santosa (2008) yaitu: a) Kemampuan mengamati, b) Kemampuan Menghitung, c) Kemampuan Mengukur, d) Kemampuan mengklasifikasikan c) Kemampuan Menemukan Hubungan, d) Kemampuan Membuat Prediksi, e) Kemampuan Melaksanakan Penelitian, f) Kemampuan Mengumpulkan dan Menganalisis Data, g) Kemampuan Mengkominikasikan 
Hasil. Menurut Syaiful (2006 :74) Pendekatan Keterampilan Proses adalah pendekatan dalam proses belajar yang menekankan pada pembentukan keterampilan memperoleh pengetahuan, dan mengkomunikasikan perolehnya. Keterampilan berarti kemampuan menggunakan pikiran, nalar, dan pembuatan secara efesien dan efektif.

Tujuan penelitian ini adalah mendiskripsikan pembelajaran dengan menggunakan pendekatan keterampilan proses untuk meningkatkan hasil belajar siswa pada pelajaran bahasa indonesia materi cerita anak kelas V SDN Danawinangun.

\section{Metode Penelitian}

Metode penelitian ini mengunakan model Penelitian Tindakan Kelas (PTK) disebut sebagai classroom action research. Prosedur penelitian yang akan dilakukan dalam penelitian tindakan kelas ini adalah model spiral kemmis dan mc.taggart (Wiriaatmadja, 2005) yaitu model siklus yang dilakukan secara berulang, berkelanjutan. Artinya semakin lama diharapkan semakin meningkatkan pencapaian hasilnya. Model ini dimulai dengan rencan, tindakan, pengamatan, refleksi dan perencanaan kembali merupakan dasar untuk ancangancang pemecahan permasalahan. Adapun model penelitian menggunakan model spiral seperti gambar dibawah ini:

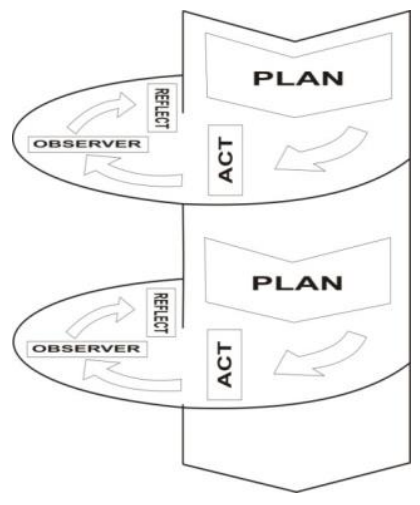

\section{Gambar 1. Model Spiral Kemmis dan Taggart}

Dari gambar 1 secara lebih rinci dapat dijelaskan sebagai berikut: a) Perencaan Tindakan (plan) Menutur Wiriaatmadja (2005 : 66) pada kegiatan perencanaan tindakan penelititan melakukan hal-hal sebagai berikut : 1) Melakukan pengamatan (observasi) awal, 2) Melakukan wawancara awal dengan objek penelitian, 3) Merancang strategi untuk mengatasi masalah tersebut. b) Pelaksaan Tindakan (act). Pada kegiatan pelaksanaan tindakan ini menurut Wiriaatmadja (2005 : 67) peneliti melakukan "kegiatan yang dimulai dari mengajukan pertanyaan-pertanyaan kepada siswa untuk mendorong mereka mengatakan apa yang mereka pahami, dan apa yang mereka minati". c) Observasi (observe). Peneliti melakukan observasi terhadap pelaksanaan dan hasil tindakan tersebut yang dilaksanakan bersamaan dengan dilaksanakannya tindakan. Menurut Wiriaatmadja (2005 : 67) pada kegiatan observasi ini "peneliti mencatat pertanyaan-pertanyaan dan jawaban-jawaban siswa atau merekamnya untuk melihat apa yang sedang terjadi". Pada kegiatan ini juga peneliti membuat catatan dalam buku hariannya. d) Refleksi (reflect) Refleksi merupakan kegiatan analisis, sintesis, interpretasi dan eksplanasi (penjelasan) terhadap semua informasi yang diperoleh dari penelitain tindakan dalam PTK. Refleksi tidak hanya dilakukan diakhir pelaksanaan tindakan. 
Hal ini sesuai dengan pendapat Wirata, dkk (2005) yang menyatakan bahwa "apabila control kelas yang dilakukan terlalu ketat menyebabkan Tanya jawab kurang lancar dilaksanakan sehingga tidak mencapai hasil yang baik, dan perlu diperbaiki." Pengolahan data proses adalah alat pengumpul data yang berupa observasi dan wawancara yang selanjutnya di diskusikan dengan guru kelas V untuk memebahas data ini. Data yang diperoleh mengenai kinerja guru dan aktivitas siswa dalam pembelajaran. Pada observasi data diolah secara prosentase sedangkan pada wawncara data diolah secara deskriptif.

$$
\begin{aligned}
\text { Persentase } & =\frac{\text { jumblah skor yang diperoleh guru }}{\text { Jumlah aspek yang diamatai }} \times 100 \% \\
& \mathrm{NP}=\frac{R}{\text { Sm }} \times 100 \% \\
& \text { Keterangan : } \quad=\text { Nilai prestasi yang diharapkan } \\
\mathrm{NP} & =\text { Skor Mentah } \\
\mathrm{R} & =\text { Skor Maksismum }
\end{aligned}
$$

Teknik pengolahan data hasil dilakukan secara kuantitatif untuk mengukur sejauh mana ketercapaian pemahaman siswa terhadap materi cerita anak. Data hasil diperoleh dari jawaban siswa terhadap tes tertulis yang diberikan guru. Adapun proses penghitungan data hasil adalah sebagai berikut:

1) Jumlah soal terdiri dari 10 nomor

2) Setiap nomor soal mendapatkan skor 10

3) Skor ideal 10 nomor soal dikali jumlah skor ideal dari setiap nomor yaitu 10. Jadi skor ideal $=10 \times 10=100$

$$
\text { Nilai }=\frac{\text { skor } \text { yang diperoleh }}{\text { jumblah skor ideal }} \times 100
$$

\section{Hasil dan Pembahasan}

Berdasarkan hasil pelaksanaan penelitian tindakan kelas pelajaran bahasa indonesia tentang materi cerita anak di kelas $\mathrm{V}$ paparan tindakan siklus I meliputi paparan data perencanaan, paparan proses, paparan hasil, serta analisis refleksi. Kegiatan pada tahap perencanaan yang dilakukan peneliti dan guru kelas $\mathrm{V}$ melakukan kolaborasi untuk menyusun rencana tindakan penggunaan pendekatan keterampilan proses sebagai upaya pemecahan masalah pada pembelajaran bahasa indonesia materi cerita anak. Yang selanjutnya membuat Rencana Pelaksanaan Pembelajaran (RPP) sebagai pedoman kegiatan belajar pada siklus I. Selain itu peneliti juga menyusun instrumen pengumpul data, instrumen pengumpul data yang akan digunakan adalah pedoman observasi, pedoman wawancara, Lembar Kerja Siswa (LKS) dan soal tes untuk mengukur kemampuan dan pemahaman siswa dalam upaya sejauh mana meningkatnya hasil belajar siswa.

Berdasarkan treatment siklus I perolehan skor rata-rata 6,1 dari nilai ketuntasan 6,8 hal ini menunjukan siswa pada siklus I mengalami peningkatan dari data awa 21,7\% menjadi 50\% selain itu perolehan nilai rata-rata kelas mengalami peningkatan dari data awal 5,7 menjadi 6,1. Sedagkan siswa yang dinyatakan lulus pada data awal sebanyak 21,7\% atau 5 siswa. Namun pada pelaksanaan siklus I yang dinyatakan lulus sebanyak 10 siswa atau 43\%. Jadi 
masi ada 13 siswa yang dinyatakan tidak lulus atau 60\% dari 23 siswa. Adanya peningkatan dari data awal ke siklus I dapat juga dilihat pada gambar.

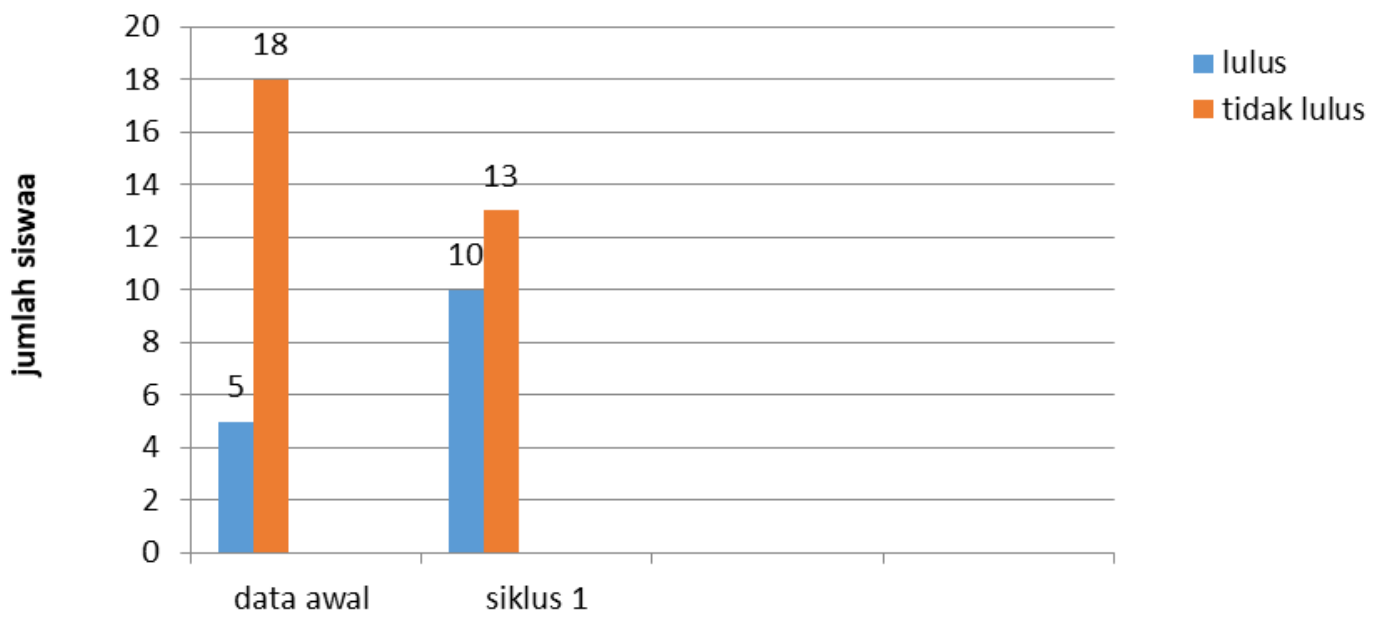

Gambar 1. Jumlah siswa lulus siklus I

Berdasarkan diagram 1 di atas, menunjukan tes hasil belajar siswa bahwa pada pelaksanaan siklus I siswa yang dinyatakan lulus sebanyak 10 siswa atau 43,4 \% dari 23 siswa. Ternyata mengalami peningkatan walaupun belum sesuai harapan. Hal ini terlihat dari penigkatan perolehan skor rata-rata siswa dan presntase kelulusan siswa, sehingga perlu perbaikan pada tindakan selanjutnya.

Pada siklus ke II peneliti menyusun kembali RPP yang telah dibuat sebelumnya dengan memperhatikan aspek-aspek yang harus diperhatikan kembali sebagai hasil dari refleksi tindakan siklus I. Selain itu disiapkan juga sarana dan prasarana yang diperlukan seperti siklus I.

Berdasarkan hasil treatment siklus II hasil tes belajar mengalami peningkatan walaupun belum $100 \%$. Hal ini terlihat dari peningkatan jumlah siswa yang lulus pada pembelajaran yang dilaksanakan disiklus II. Peningkatan kelulusan jumlah siswa setelah penerapan model pembelajaran pendekatan keterampilan proses di siklus II atau ada peningkatan dari siklus I ke siklus II bisa dilihat pada gambar berikut.

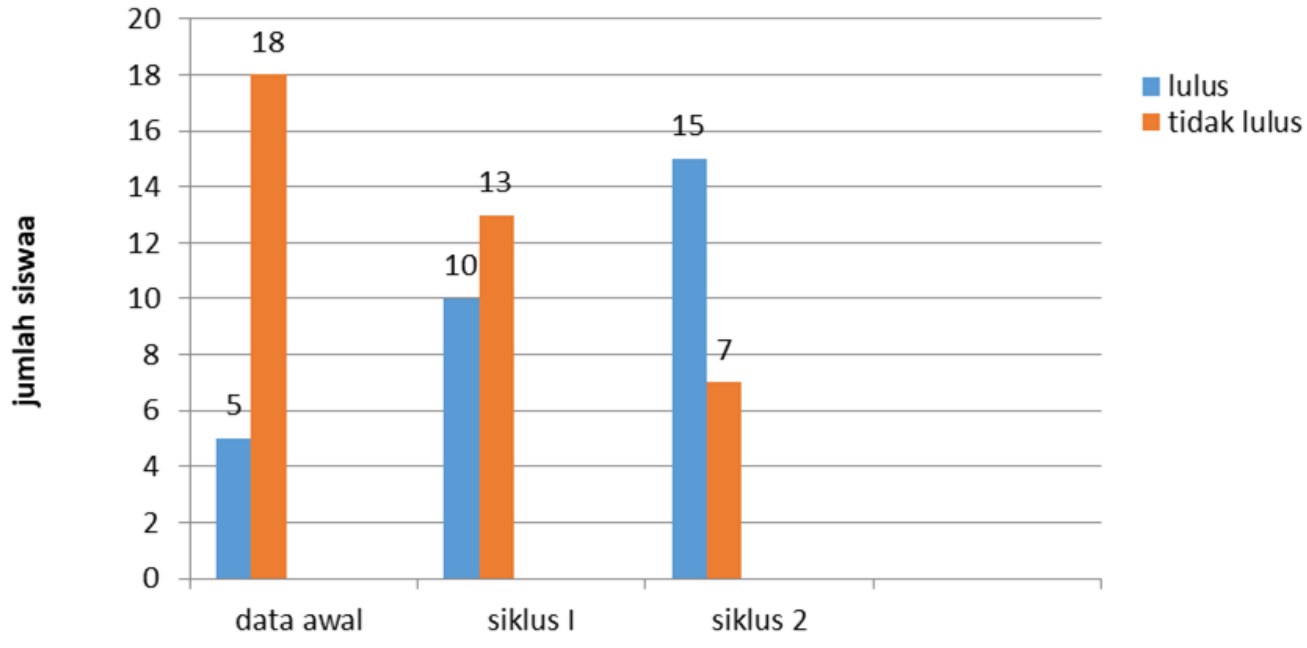

Gambar 2. Jumlah Siswa lulus Siklus I \& II 
Berdasarkan dari data awal sebelum menggunakan pendekatan keterampilan proses pada materi cerita anak dikelas $\mathrm{V}$ hasil belajar siswa yang tuntas yaitu 21,7\%. Pada siklus I setelah menggunakan Pendekatan Keterampilan Proses ada peningkatan hasil belajar siswa yang tuntas yaitu $65,2 \%$ atau naik $43,5 \%$ dari sebelumnya. Kondisi yang demikian ini semakin meningkat signifikan pada Siklus II siswa yang mencapai ketuntasan dalam pembelajaran Bahasa Indonesia meningkat sebanyak 86,9\% atau naik dari siklus I, ketuntasan belajar klasikal siswa sudah memenuhi indikator keberhasilan, oleh karena itu pembelajaran dapat dikatakan tuntas. Ketuntasan hasil belajar siswa penelitian ini membuktikan bahwa pembelajaran dengan pendekatan keterampilan proses dapat digunakan sebagai salah satu metode untuk meningkatkan hasil belajar siswa.

Penelitian ini memberikan ulasan tentang pendekatan keterampilan proses pada pelajaran bahasa indonesia tentang cerita anak di kelas $\mathrm{V}$ sekolah dasar yang diharapkan sebagai upaya meningkatkan hasil belajar siswa pada pelajaran bahasa indonesia khususnya tentang materi cerita anak kelas V. Berdasarkan hasil penelitian yang dilakukan sebanyak dua kali siklus mengenai Penggunaan Pendekatan Keterampilan Proses pada pembelajaran Cerita anak, memberikan hasil yang positif berupa terjadinya peningkatan hasil belajar siswa dan aktivitas siswa. Peningkatan tersebut didasarkan pada hasil temuan yang diperoleh dari dua kali siklus pelaksanaan tindakan.

Pada data awal dijelaskan bahwa kondisi awal siswa sebelum dilakukan perlakuan (treatmen) adalah hanya $21 \%$ siswa yang tuntas dalam pelajaran bahasa indonesia materi cerita anak dikelas $\mathrm{v}$ sekolah dasar. Beberapa siswa yang dianggap kurang memahami materi dikarenakan guru yang belum menemukan pendekatan yang sesuai dengan materi tersebut. setelah dilakukan perlaukuan (treatment) siklus II diperoleh jumlah siswa yang tuntas mencapai $86,9 \%$. Penerapan model pembelajaran menggunakan pendekatan keterampilan proses dapat meningkatkan hasil belajar siswa. Hal ini terbukti pada siklus II yang memperlihatkan terjadinya peningkatan hasil belajar siswa yang cukup signifikan.

Pendekatan Keterampilan Proses dalam pembelajaran Bahasa adalah pendekatan yang memberikan seluas-luasnya kepada siswa secara aktif dan kreatif dalam proses pemerolehan bahasa. Pendekan ini di pandang sebagai pendekatan dalam proses belajarmengajar sesuai dengan era perkembangan Ilmu Pengetahuan dan teknologi. Pendekatan ini memberikan pengetahuan, pengalaman, keterampilan yang cocok untuk memperoleh serta mengembangkan kompetensi bahasa yang kita pelajari. Dalam hal ini Bahasa Indonesia. Fokus pembelajaranya tidak hanya fokus pada pencapaian tujuan pemberian tugas saja, melaikan memberian pengetahuan, pengalaman mencapai tujuan pembelajaran tersebut. Pengelolahan kelas dalam pembelajaran dengan Pendekatan Proses dilakukan dengan pengaturan dikelas. Baik secara fisik maupun nonfisik, Pengaturan dilakukan sedemikian rupa agar siswa memliki keleluasaan gerak, merasa aman, bergembiraa, bersemangat, dan bergairah untuk belajar. Dengan kondisi yang demikian, materi yang diberikan kepada siswa akan mencapai hasil maksimal.

Metode didefinisikan sebagai cara teratur yang digunakan untuk melaksanakan suatu pekerjaan agar tercapai sesuai yang dikehendaki (Kamus Besar Bahasa Indonesia, 2001). Penerapan pembelajarn bahasa Indonesia harus dikerjakan menurut langkah-langkah yang teratur, bertahap yakni mulai merencanakan pembelajaran penyajian, sampai dengan penilaian dan hasil pembelajaran. Beberapa faktor yang dapat memperngaruhi terhadap 
metode pembelajaran bahasa Indonesia, antara lain: a) Persamaan antara sistem bahasa pertama siswa dengan bahasa kedua yang meraka pelajari, b) Usia siswa pada saat mereka belajar bahasa, c) Latar belakang sosial budaya siswa, d) Pengalaman, pengetahuan, dan keterampilan bahasa siswa dalam bahasa yang dipelajari yang sudah mereka punya, e) Pengetahuan dan keterampilan berbahasa siswa dalam bahasa yang akan dipelajari, f) Kedudukan dan fungsi bahasa yang dipelajari dalam masyarakat dimana mereka berada, g) Tujuan pembelajaran yang diinginkan, i) Alokasi waktu yang tersedia untuk kegiatan pembelajaran.

Cerita anak adalah cerita yang ditulis untuk anak, yang berbicara mengenai kehidupan anak dan sekitarnya yang mempengaruhi anak, dan tulisan ini hanyalah dapat dinikmati oleh anak dengan bantuan orang dewasa. Sejalan dengan pendapat tersebut Endaswara mendefinasikan cerita anak adalah cerita yang mencerminkan liku-liku kehidupan yang dapat dipahami oleh anak, melukiskan perasaan penggambaran pemikiran-pemikiran anak . pada dasarnya merupakan cerita sederhana yang kompleks. Kesederhanaan ini ditandai oleh wacana yang baku dan berkualitas tinggi, namun tidak sulit, sehingga Komunikatif. Cerita anak termasuk jenis prosa jadi dapat disimpulkan Cerita anak adalah cerita yang ditulis untuk anak mengenai kehidupan anak, lingkungan yang mempengaruhinya dan melukiskan perasaan serta pemikiran-pemikiran. Menurut Santoso (2003) sastra anak adalah karya yang imajinatif dengan unsur estentisnya dominan yang bermodium bahasa baik lisan maupun tulisan secara khusus yang dapat dipahami oleh anak- anak anak. Sementara itu menurut Sarumpaet (Dalam Santoso, 2003, 8-3), sastra anak adalah karya yang ditulis karya yang dikonsumsi anak yang diurus serta dikerjakan oleh orang tua. Artinya, sastra anak adalah oleh orang tua yang ditunjukan kepada anak oleh proses produksinyapun dikerjakan oleh orang tua.

Sifat satra anak adalah imajinasi sementara bahkan berdasarkan pada fakta, Unsur imajinasi sangat menonjol dalam sastra anak. Hakikat sastra harus sesuai dengan dunia dan alam anak-anak bukan milik orang dewasa. Sastra anak bertumpu dan bernilai pada penyajian nilai dan imbauan yang di anggap sebagai pedoman. (Wahidin, 2009)

Perkembangan anak akan wajar dan berjalan sesuai dengan priodenya bila disuguhkan dengan bahan bacaan yang sesuai pula. Sastra yang akan dikomsumsikan bagi anak harus mengandung tema yang mendidik, alurnya lurus, dan tidak berbelit-belit, menggunkan setting yang ada disekitar tokoh dan penokohan mengandung peneladanan yang baik, gaya bahasa mudah dipahami tapi mampu mengembangkan bahasa anak, sudut pandang orang yang tepat, dan imajinasi masih dalam jangkauan anak isi kandungan yang terbatas sesuai dengan jangkauan emosional dan psikolgi anak itulah yang anatara lain, merupakan karaktaristik sastra anak. Sastra anak dapat berkisah tentang apa saja, bahkan menurut ukuran dewasa tidak masuk akal. Menurut Titik (2003) menjelaskan anak adalah cerita sederhana yang kompleks. Kesederhanaan itu ditandai oleh syarat wacana yang baku dan berkualitas tinggi, namun tidak ruwet sehingga komunikatif. Cerita anak harus berbica tentang kehidupan anak-anak aspek yang berada dan mempengaruhi mereka.

Cerita anak dikatakan juga sebagai suatu yang kompleks, artinya cerita anak dibangun oleh stuktur yang tidak berbeda dengan cerita orang dewasa, sebab cerita anak-anak yang sederhana itu harus tetap disusun dengan memperhatikan unsur keindahan dan kemenarikan. Sebuah ceirta akan menjadi menarik jika semua elemen kisah atau cerita dibina 
secara seimbang didalam stuktur yang dapat saling mengisi sehingga tidak terjadi penyimpangan. Rancang bangun cerita anak-anak sangat menentukan menarik tidaknya sebuah cerita anak-anak dan disinlah letak kopmleksitas yang tinggi yang tedrdapat dalam cerita anak.

Menurut Puryanto (2008) secara garis besar dan syarat cerita anak / sastra anak adalah: Cerita anak mengandung tema yang mendidik, alurnya lurus dan tidak berbelit-belit menggunakan setting yang ada disekitar atau ada di dunia anak tokoh dan penokohan mengandung keteladanan yang baik, gaya bahasa mudah dipahami, mengembangkan bahasa anak, sudut pandang orang yang tepat dan imajinasi dalam jangkauan. Menurut Rosdiana (2009) ciri-ciri cerita anak sebagai berikut: a) Unsur Pantangan, b) Penyajian, c) Fungsi Terapan. Lebih lanjut Rosdiana (2009) menyebutkan Cerita anak-anak dapat menjadi sahabat karib bagi anak-anak, dapat juga dibaca saat menjelang tidur, pada waktu senggang, atau pada waktu diaadakan secara khusus. Cerita yang dapat memberikan pandangan tentang rasa percaya diri pada anak, rasa aman, tentram, sebagai anggota keluarga, anggota lingkungan sekolah, dan masyarakat. Ditinjau dari segi bahasa cerita anak-anak dapat memperkaya perbendaharaan kata anak-anak, menjadikan anak terampil berbahasa secara lisan atau tulisan. Dari cerita anak-anak bukan saja dapat mengetahui perkara baru, tetapi juga dapat meningkatkan minat terhadap hal-hal yang baru.

Hasil belajar merupakan pola-pola perbuatan, nilai-nilai, pengertian-pengertian, sikap-sikap, apresiasi dan keterampilan merujuk pemikiran Giane (Agus Suprijono, 2009). Kemudian menurut Oemar Hamalik hasil belajar adalah bila seseorang telah akan terjadi perubahan tingkah laku pada seseorang tersebut misalnya dari tidak mengeti menjadi mengerti dan tidak tahu menjadi tahu.

Gloria (2013) menyatakan bahwa hasil belajar siswa yang menggunakan ketrampilan proses mengalami peningkatan lebih tinggi dibandingkan dengan yang tidak mengunakan keterampilan proses.

Berdasarkan pada PP. Nomer 19 tentang Standar Nasional Pendidikan pasal 64 ayat (1) dijelaskan bahwa penilaian hasil belajar oleh pendidik dilakukan secara berkesanambungan untuk memantau proses, kemajuan, dan perbaikan hasil belajar dalam bentuk ulangn harian, ulangan tengah semester, ulangan akhir semester dan ulangan kenaikan kelas . selanjutnya ayat (2) menjelaskan bahwa penelian hasil belajar oleh pendidik digunakan untuk (a) menilai penvapaian kompetensi peserta didik (b) bahan penyusunan laporan hasil kemajuan hasil belajar dan (c) memperbaiki proses pembelajaran. Dari pendapat banyak ahli menyimpulkan hasil belajar menjadi tolak ukur adalah berupa nilai-nilai yang diperolehnya. Nilai itu diperoleh siswa setelah siswa melakukan proses pembelajaran dalam kurun waktu tertentu dan selanjutnya melakukan tes ujian akhir (ujian). Dalam sistem pendidikan nasional tujuan pendidikan, baik tujuan kurikuler maupun tujuan intruksional, menggunakan klasifikasi hasil belajar dari Benyamin Bloom yang secara garis besar menbaginya menjadi tiga ranah yakni ranah kognitif, ranah afektif dan ranah psikomotoris. Ranah kognitif berkenaan dengan hasil belajar yang terdiri atas enam aspek yakni pengalaman atau ingatan, pemahaman, aplikasi, analisis, sintesis, dan evaluasi. Kedua aspek pertama dan kognitif tingkat rendah dan keempat aspek berikutnya termasuk kognitif tingkat tinggi.

Ranah efektif berkenaan dengan sikap yang terdiri atas lima aspek yakni penerimaan, jawaban atau reaksi, penilaian, organiasasi dan internalisasi. Ranah psikomotoris berkenaan dengan hasil belajar keterampilan dan kemampuan bertindak. Ada enam aspek ranah psikomotoris yakni gerakan refleks, keterampilan,gerakan dasar, kemampuan 
kompleks, dan gerakan ekspresif dan interpretatif. Ketiga ranah tersebut menjadi objek penilaian hasil belajar. Dianatara ketiga aranah tersebut, ranah kognitif yang paling banyak dinilai oleh para guru di sekolah karena berkaitan dengan kemampuan para siswa menguasai bahan pengajaran. Dan dengan alasan itu juga peneliti memilih ranah kognitif untuk mengukur kemampuan siswa dalam penelitianya.

Adapun permasalahan yang telah dipaparkan di atas, maka rumusan masalah penelitian ini adalah "Bagaimana penerapan pendekatan keterampilan proses dapat meningkatkan hasil belajar siswa pada materi cerita anak pelajaran bahasa indonesia di kelas V SD". Berdasarkan rumusan masalah di atas, maka dapat ditetapkan tujuan penelitian ini adalah untuk mengetahui perencanaan, penerapan dan peningkatan hasil belajar siswa dengan menggunakan pendekatan keterampilan proses pada materi cerita anak pelajaran Bahasa Indonesia di kelas V SD.

Hasil penelitian yang telah diuraikan di atas, penerapan model pembelajaran dengan pendekatan ketrampilan proses pada pelajaran bahasa indonesia materi cerita anak di kelas $\mathrm{V}$ SDN 1 Danawinangun mengalami peningkatan pada akhir siklus yang selaras dengan penelitian yang dilakukan oleh Rismaerista dan Mawardi (2015), Rahayu, Susanto, dan Yulianti (2011), Biliya (2015), Usman, R (2018), dan Thalib, A (2018) yang menyimpulkan bahwa pendekatan ketrampilan proses mampu meningkatkan hasil belajar siswa.

\section{Kesimpulan}

Berdasarkan hasil penelitian dan pembahasan dapat disimpulkan bahwa penggunaan pendekatan keterampilan proses pada materi cerita anak dikelas $\mathrm{V}$ bisa meningkatkan hasil belajar siswa. Hal tersebut diuraikan dengan hasil penelitian yang membandingkat hasil siklus kedua jika dibandingkan dengan siklus pertama mengalami peningkatan hasil belajar. Apabila dibandingkan dengan siklus ke II yang mencapai 86,9\% ketuntasan klasikal atau naik dari siklus I yang tuntas 65,2\%. Dapat disimpulkan pelaksanaan penelitian tindakan kelas mulai siklus I sampai siklus II mengalami peningkatan.

\section{Daftar Pustaka}

Agus, S. (2009). Cooperative Learning: Teori dan Aplikasi PAIKEM. Yogyakarta : Pustaka Pelajar

Akbar, S. (2013). Instrumen Perangkat Pemebelajaran.Bandung:Remaja Rosdakarya

Arikunto, S. (2014). Penelitian Tindakan Kelas. Jakarta:Bumi Askara

Aritonang, K. T. (2008). Minat dan motivasi dalam meningkatkan hasil belajar siswa. Jurnal pendidikan penabur, $7(10), 11-21$.

Biliya, B. (2015). Penerapan Model Open Ended untuk Meningkatkan Keterampilan Proses dan Hasil Belajar Siswa Kelas V SDN 1 Repaking-Wonosegoro-Boyolali. Scholaria: Jurnal Pendidikan dan Kebudayaan, 5(1), 78-91.

Gloria, R. Y. (2013). Penerapan pendekatan keterampilan proses dalam pengajaran biologi untuk mengetahui hasil belajar siswa pada pokok bahasan ekosistem kelas VII di SMPN 1 TALUN.

Nasution, M. K. (2018). Penggunaan metode pembelajaran dalam peningkatan hasil belajar siswa. Studia Didaktika, 11(01), 9-16. 
Nurhasanah, S., \& Sobandi, A. (2016). Minat belajar sebagai determinan hasil belajar siswa. Jurnal Pendidikan Manajemen Perkantoran (JPManper), 1(1), 128-135.

Purwanto. Evaluasi Hasil Belajar, Yogyakarta: Pustaka Pelajar, 2009

Rini, R., \& Mawardi, M. (2015). Peningkatan Keterampilan Proses Saintifik dan Hasil Belajar Siswa Kelas 4 SDN Slungkep 02 Tema Peduli Terhadap Makhluk Hidup Menggunakan Model Problem Based Learning. Scholaria: Jurnal Pendidikan dan Kebudayaan, 5(1), 103113.

Rochiati, W. (2005). Metode Penelitian Tindakan Kelas. Bandung: PT. Remaja Rosdakarya

Rosdiana. (2009). Parasitologi kedokteran: Protozologi, Helmintologi,. Entomologi. CV. Trima Widya: Bandung

Rustan, E. (2017). Learning Creative Writing Model Based on Neurolinguistic Programming. International Journal of Language Education and Culture Review, 3(2), 13-29.

Thalib, A. (2018). Pendekatan Keterampilan Proses Dalam Meningkatkan Hasil Belajar Bahasa Indonesia. Pedagogik Journal of Islamic Elementary School, 1(1), 23-36.

Usman, R. (2018). Penggunaan Metode Keterampilan Proses untuk Meningkatkan Aktivitas dan Hasil Belajar Bahasa Indonesia melalui Telepon Siswa Kelas IV SD Negeri 02 Kundur. GERAM, 6(2), 67-76. 